minute details and lessen the labour of the student in acquiring sufficient knowledge of anatomy to satisfy the medical curriculum. There has been going on for some time the discussion as to whether the teaching of anatomy as was done elaborately to give a sound foundation to the student for preparing himself for medical science, should not be curtailed materially in order to lighten the burden on him made heavy and almost unwieldy by the introduction of specialized subjects. The question will be decided after experience has been gathered for a few years. The book under has been gather of information which is extraordinarily compressed in a volume of this size. The information is well laid out in a systematic manne infor will afford the students much help in their dissections. It appears to be a further development improved considerably of another book which Wright improved considerably of another bours ago and which is mentioned in the preface of this work.

The book ought to be useful and popular with the students.

L. M. B.

BUCHANAN'S MANUAL OF ANATOMY.-Edited by F. Wood Jones, D.Sc. (Lond., Adelaide and Melb.), M.Sc. (Manch.), M.B., B.S. (Lond.), F.R.S., F.R.C.s. (Eng.). Assisted by E. L. Patterson, M.D., B.Sc. (Manch.), et al. Seventh Edition. 1946. Ballitière, Tindall and Cox, London. Pp. vill plus 1616. Illustrated. Price, 45s.

THe new edition of this well-known work contain The old scheme of regional description is maintained which makes it different from dether well-known books on anatomy. This scheme has its a was as its disadvantages inasmuch its a follow the as one has to turn to different regions to for different whole course of a structure which traverses different regions. The descriptions of structures are terse and easy to follow. The diagrams are practically all original and many new ones have been added. These are clear and true. A new feature is inclusion of are clear and true. A new feature display structures several skiagrams which beautifuly display structure giving shadows in their original relations. The organogenesis portion has been shortened, thus involving consultation of a more elaborate work on the subject. It is a textbook popular among students of anatomy and they will

\section{M. B.}

GARDINER'S HANDBOOK OF SKIN DISEASES.Revised by John Kinnear, O.B.E., T.D., M.D., M.R.C.P. (Edin.), D.L. Fifth Edition. 1948 E. $\dot{S}$. Livingstone Limited, Edinburgh. Pp. $x$ plus 250. Illustrated. Price, 15s.; postage, 6d. (home)

Messrs. E. And S. Livingstone Ltd. deserve conratulation for the new edition of this little book for the beginners. Many important informations from recent works have been given and the appendix will be found very useful.

This is a good book for the nurses and students for whom it is intended although it cannot be classed as a standard book on dermatology.

The printing and get-up are good.

THE PRACTICE OF MENTAL NURSING.-BY $M$. Houliston, R.G.N., R.M.N., R.F.N. 1947. E. and S Livingstone, Limited, Edinburgh. Pp. xi plus 164. Livingstone,
Price, 7s. 6d.

As invaluable aid for new entrants of mental nursing. A good guide to any nurse attending neurotic patients. C. M. A.

A HANDBOOK FOR NURSERY NURSES.-BY A. B. Muring, S.R.N. 1947. Baillière, Tindall and Cox London. Pp. xi plus 509 . Illustrated. Price, London.

RECOMMENDABLE for nursery nurses in training, also very helpful in the homes of young children.

C. M. A
ELEMENTARY HYGIENE FOR NURSES : A HANDBOOK FOR NURSES AND OTHERS.-By H. C. Rutherford Darling, M.D., M.S. (Lond.), F.R.C.S (Eng.), F.R.F.P.S. (Glas.). Ninth Edition. 1947. J, and A. Churchill Limited, London. Pp. vill plus 296. Illustrated. Price, 7s. 6d.

A USEFUL book for 1st year nurses or preliminary training school. Illustrations instructive.

C. M. A.

MEDICAL RESEARCH COUNCIL. SPECIAL REPORT SERIES NO. 257. A STUDY OF INDIVIDUAL CHILDREN'S DIETS.-BY E. M. WIddowson. 1947. Published by His Majesty's Stationery Office, London. Pp. vii plus 196. Illustrated. Price, 6s.

DIETARY survevs are usually carried out on groups of persons in institutions or families by measuring the food consumption and working out the average by simple calculation. Although useful for some purposes, the method does not give any picture of what an individual child eats, nor does it show the variations between one child and another. Dr. Widdowson's report differs in that she investigated the diets of individual children, what food, in kind and quality, was actually consumed by each child in selected groups. The method employed was to weigh the food eaten over a period of one week by each child and calculate its chemical composition from food tables. At the same time the heights and weights of the children were measured and frequently also the blood and teeth were examined. In this way data were collected from over 1,000 British children, most of them coming from 'middle class' homes. At least 20 boys and 20 girls were investigated at every year of age from 1 to 18 thus covering the whole range of childhood. They were healthy children, but for comparison some who were diabetics or the offspring of impoverished parents were included within the scope of this study. It must have been a very laborious task to collect the data and analyse the results which are presented in this report. While these should be of value to those concerned in the feeding of children, the one outstanding fact that emerges from this investigation is that similar individuals may differ enormously in their food habits. In each age group studied, for instance, there was always one child who ate as much as another, and similar differences were found when children of the same height and weight or surface area are compared. And yet such variations may be compatible with good health and average physical development. The findings indicate that individual requirements must differ as much as individual intakes and that an average intake should never be used to assess an individual's requirement. The report which has been prepared with great care may open up new lines of research in the field of nutrition and should be a model to those undertaking dietary investigations in this country.

R. N. C.

\section{DIE HORMONVERSORGUNG DES FCETUS.-BY \\ Dr. Jules Samuels. 1947. E. J. Brill, Leiden,} Holland. Pp. 320

In this book the author discusses the hormonal supply of the fœetus. However the discussion is limited to the activity of the secretions of the anterior lobe of the hypophysis and to the anterior-pituitary like secretions of the placenta. Dr. Samuels concludes that these substances are not only activators of cellproliferation, but he believes them also to be the growth factors of the fœtus. The author is of the opinion that the first stage of fœtal development is under the hormonal influence of the maternal anterior pituitary, while formation of the chorion and of the placenta initiate the second stage of development which is regulated by the hormonal secretions of the placenta. The latter produces some anterior-pituitary like hormone, the action of which is similar to that of progesterone

The author states that only two, and not several. hormones are produced in the anterior adenohypophysis, i.e. the basophil cells secrete a gonadotrop hormone 